\title{
PEMIKIRAN KEAGAMAAN MAHASISWA ISLAM PERGURUAN TINGGI UMUM NEGERI
}

Oleh: Suprapto

\begin{abstract}
This study focuses on how is religious thought of Muslim students in Public Colleges? Is it exclusive, inclusive, or liberal? And how far is the level of exclusivism, inclusivism or liberalism of their religious thoughts? The research findings showed that religious thoughts of Muslim students in Public Colleges tended to be exclusive and inclusive. The tendency of their religious thought was more strongly influenced by religious thoughts and activities at intra-campus organizations. The implication was religious guidance for Muslim students of Public Colleges, particularly those studying about IslamicEducation, needed to consider thetendency of religious thought of Muslimstudents, especially from curriculum preparation aspects and religion learning models.
\end{abstract}

Keywords:Inclusive, Exclusive and Liberal

\section{Abstrak}

Masalah utama dalam penelitian ini adalah bagaimana pemikiran keagamaan mahasiswa Islam di Perguruan Tinggi Umum (PTU) Negeri, apakah eksklusif, inklusif, ataukah liberal? Dan seberapa jauh tingkat eksklusivisme, inklusivisme, atau liberalisme berpikir keagamaan mereka? Hasil penelitian menunjukkan bahwa pemikiran keagamaan mahasiswa Islam PTU Negericenderung eksklusif dan insklusif. Kecenderungan berpikir keagamaan mereka lebih kuat dipengaruhi oleh aktivitas dan pemikiran keagamaan di intra kampus. Implikasinya, pembinaan keagamaan bagi mahasiswa Islam PTU Negeri khususnya perkuliahan Pendidikan Agama Islam perlu mempertimbangkan kecenderungan pemikirankeagamaanmahasiswalslam, terutamadariaspekpenyusunankurikulumdanmodel-model pembelajaran agama.

Kata Kunci: Inklusif, eksklusif dan liberal

\section{PENDAHULUAN}

Dunia Pendidikan di Indonesia sampai dengan saat ini dihadapkan beragam tantangan. Pada sisi ekternal, lembaga Pendidikan dihadapkan pada tuntutan perubahan sesuai perkembangan global, dalam ranah internal, kita juga diarahkan untuk melakukan evaluasi atas pelbagai hal yang terkait dengan arah perjalanan dunia
Pendidikan, mulai dari keterlengkapan infrastruktur hingga perangkat penting lain seperti keberadaan dosen dan mahasiswa.

Melihat perkembangan lembaga Pendidikan tinggi di Indonesia, sekiranya beberapa pertanyaan penting akan mengemuka seiring kondisi yang terjadi. Salah satunya adalah tentang bagaimana suasana keberagamaan di lingkungan kampus saat ini. Karena tentu, selain problem mahalnya

Naskah diterima, 15 Januari 2012. Revisi pertama, 31 Januari 2012, revisi kedua 15 Februari 2012, revisi ketiga 30 Maret 2012 
biaya Pendidikan, lembaga Pendidikan inipun memiliki ragam permasalahan lain.

Dalam ranah pengajaran, problem muncul tatkala dalam faktanya, sebagian pengajar (dosen) hadir melalui metode yang tak memadai. Sebuah riset yang dilakukan Program Studi Agama dan Lintas Budaya (CRCS) UGM, JogJakarta menujukkan betapa pengajaran agama di perguruan tinggi selain tidak memadai dari banyak segi yang pada akhirnya berpengaruh pada pemikiran keagamaan di kalangan mahasiswa yang cenderung sangat eksklusif. Problem lain tampak pada tararan sistem di mana dalam beberapa kasus cendrung terjadinya pergeseran orientasi mahasiswa ke taraf yang lebih luas. Dari orientasi yang awalnya sekedar mengunggulkan mutu akademis, menuju ke arah ruang khusus sebagai dakwah agama yang mengakibatkan: pertama, munculnya mahasiswa aktivis organisasi Islam, baik intra maupun ekstra, baik organisasi keagamaan maupun bukan dibanding dengan non aktivis, mereka lebih kritis dan dinamis dalam menyikapi perkembangan kehidupan beragama dan bermasyarakat. Diduga kuat, bahwa yang menjadi penggeraknya adalah mereka para aktivis mahasiswa Islam yang ingin mencari keadilan. Kedua, mahasiswa aktivis Islam mungkin karena panggilan dakwah dan kewajiban amar ma'ruf dan nahi munkar biasanya sangat aktif mensosialisasikan corak berpikir keagamanya. Bila benar, maka tugas pembinaan IMTAQ meIalui mata kuliah Pendidikan Agama Islam di PTU sangat dibantu oleh mereka agar pemikiran dan gerakan mereka produktif dan terarah. Tetapi jika tidak, misalnya ekstrim eksklusif, tentu membahayakan bagi terwujudnya tujuan Pendidikan Nasional. Secara umum, corak berpikir dan aktivitas keagamaan mahasiswa dapat dipetakan pada tiga (3) kelompok sebagai berikut: pertama, Kelompok "common" muslim, yakni para mahasiswa muslim yang mengamalkan ajaran Islam seadanya serta cenderung tradisional dan konvensional.
Ini merupakan kelompok mayoritas; kedua, Kelompok mahasiswa yang berlatar belakang keagamaan sangat kuat, mereka merasa perlu mengembangkan dirinya untuk memahami Islam dalam konteks akademik untuk pengalaman berorganisasi dan keterampilan ilmiah mereka; dan ketiga, Kelompok mahasiswa yang berorientasi kepada pengamalan Islam secara menyeluruh, kaffah.

Fenomena tersebut, di satu sisi cukup menggembirakan, karena para anak muda peduli dan semangat mendiskusikan persoalan-persoalan keagamaan; namun di sisi lain ada kekhawatiran munculnya aliaran "sempalan" sebagai akibat dari ketidakpuasan mereka terhadap pemikiran-pemikiran keagamaan yang mereka dapatkan dari hasil kajiannya. Indikastor ke arah itu sudah nampak ketika kita melihat kehidupan beragama di kalangan para aktivis muda Islam seperti sikapsikap beragama yang dikotomis. Hasil pengamatan peneliti ditemukan kelompokkelompok yang berpikir eksklusif, namun di sisi lain ada kelompok aktivis yang berpikir inklusif bahkan liberal. Kelompok eksklusif mereka cenderung menutup diri dan memandang bahwa kelompok lain keliru. Sementara itu, kelompok inklusif lebih toleran terhadap pendapat orang lain. Sedangkan yang liberal, mereka sangat bebas lagi, bukan hanya toleran bahkan memandang semua pendapat itu benar selama rasional. Kelompok liberal seringkali menyampaikan pikran-pikiran yang cenderung kontroversial.

Masalah utama yang menjadi fokus penelitian ini adalah bagaimanakah pemikiran keagamaan mahasiswa Islam di PTU Negeri Terkemuka di Indonesia? Apakah eksklusif, inklusif, ataukah liberal? Serta seberapa jauh tingkat eksklusivisme, inklusivisme, atau liberalisme corak berpikir keagamaan mereka?

Penelitian ini bertujuan untuk memetakan pemikiran keagamaan mahasiswa 
aktivis Islam di PTU Negeri: Apakah pemikiran mereka eksklusif, inklusif, atau liberal? Pada tingkatan mana eksklusifisme, inklusifisme, dan liberalisme pemikiran keagamaan mereka; apakah ada pada tingkat ekstrim atau moderat? Serta mencari hubungan asosiatif antara pemikiran keagamaan dengan latar belakang sosiokeagamaan mereka; adakah hubungan korelasi antara corak berpikir keagamaan dengan pelaksanaan kuliah Pendidikan agama Islam?

\section{KAJIAN PUSTAKA}

Studi ini didasarkan pada konsep kelompok social (social groups). Menurut Merlon (1965) ada tiga kriteria objektif yang membangun sebuah kelompok, yaitu: sering terjadinya interaksi, pihak yang berinteraksi mendefinisikan dirinya sebagai anggota, dan pihak yang berinteraksi didefinisikan oleh orang lain sebagai anggota kelompok. Sedangkan pemikiran keagamaan diartikan sebagai usaha untuk mentaranformasikan ide-ide keagamaan ke dalam bentuk kegiatan untuk membuat tatanan social yang lebih baik.

Menurut Azyumardi Azra, ada tiga (3) tipe pemikiran keagamaan mahasiswa yaitu:1

1. Ekslusivisme ekstrim adalah jenis eksklusivisme yang sangat tertutup, dikotomis (benar-salah), dan radikal. Kelompok ini hanya membenarkan mazhabnya sendiri dengan serta merta menyalahkan, menyesatkan, dan mengkafirkan mazhab lain. Eksklusivisme moderat hanyalah sebatas membenarkan mazhabnya dan menyalahkan atau menyesatkan mazhab lain, tanpa mengkafirkannya.

2. Inklusifisme tinggi adalah Liberalisme moderat, plus keyakinan adanya sejum-

1 Azyumardi Azra, 2002, Konflik Baru Antar Peradaban: Globalisasi, Radikalisme dan Pluralitas, Jakarta: RajaGrafindo Persada, hal. 224. lah non-Muslim yang bisa selamat (masuk surga) karena beriman kepada Allah, kepada hari akhir, dan beramal saleh.

3. Liberalisme ekstrim adalah kelompok yang tidak lagi membeda-bedakan lagi agama. Menurut kelompok ini, semua agama, terutama agama-agama besar, pada hakikatnya adalah Islam. Karena itu, semua agama -karena sama-sama Islam- adalah benar. Yang membedakan antara agama (yang bernama) Islam dengan agama lainnya (yang bernama bukan Islam) hanyalah dalam segi kualitasnya.

Menurut Moh. Daud Ali, bahwa secara umum tingkat keberagamaan mahasiswa di Indonesia dapat dikelompokkan ke dalam tiga (3) kelompok: 2

1. Mahasiswa yang merupakan mayoritas adalah kelompok "common" Muslim, yakni para mahasiswa Muslim yang mengamalkan ajaran Islam seadanya serta cenderung tradisional dan konvensional. Sebagian mereka bahkan tidak begitu concern terhadap agama.

2. Kelompok mahasiswa yang peduli terhadap agama dengan pemahaman yang amat sederhana terhadap agama, seperti dapat kita saksikan, hanyalah melaksanakan ajaran agama seadanya sebagaimana mereka terima dari orang tua dan lingkungan sosial-keagamaan yang biasa. Mereka memang mengamalkan ritual-ritual Islam yang pokok, seperti shalat dan puasa, tapi tidak begitu bersemangat terhadap agama.

3. Kelompok mahasiswa yang lebih berorientasi kepada pengamalan Islam secara menyeluruh, kaffah. Kelompokkelompok ini, apa karena pengaruh gerakan organisasi internasional Islam Ikhwanul Muslimin (Mesir) dan Jama`at

2 Mohammad Daud Ali, (Editor, 2002)“Fenomena 'Sempalan' Keagamaan di PTU: Sebuah Tantangan Bagi Pendidikan Agama Islam", dalam Fuaduddin \& Cik Hasan Bisri, , Dinamika Pemikiran Islam di Perguruan Tinggi, Ciputat: Logos. Hal. 85. 
Islami (Pakistan) atau hasil kreasi lokal para mahasiswa Islam Indonesia. Mereka mengadakan pengkajian-pengkajian Islam secara intensif dalam bentuk Usrah-usrah.

Menurut Din Syamsuddin, bahwa para pakar agama dan terutama pemerintah dan politisi,3 sering menyebut kelompok Islam yang eksklusif, terutama eksklusif yang ekstrim dan radikal sebagai kelompok "sempalan" Islam. Kata "sempalan" sengaja diberi tanda petik (") untuk menunjukkan suatu kelompok Islam di luar mainstream keagamaan dan sebagai kebalikan dari masyarakat Muslim pada umumnya.

\section{KERANGKA BERFIKIR}

Studi ini melakukan identifikasi dan deskripsi pola pemikiran keagamaan mahasiswa Islam perguruan tinggi umum negeri baik formal (bentukan internal kampus) maupun non formal (bentukan eksternal kampus). Dari deskripsi ini setidaknya akan terefleksi berbagai karakteristik pemikiran keagamaan mahasiswa. Pemikiran keagamaan mahasiswa Islam yang eksklusif, ekstrim - moderat, inklusif, inklusif rendah, inklusif tinggi, liberal dan moderat-ekstrim akan dipengaruhi oleh faktor jenis kelamin, program studi yang dipilih, aktivitas keagamaan, sosiao agama keluarga, dan perkuliahan Pendidikan agama Islam di PTU.

Pendidikan Agama Islam di Perguruan Tinggi Umum (PTU) bertujuan; selain membimbing keimanan, ketakwaan, dan akhlak mulia, juga untuk membina kehidupan beragama yang "inklusif" dan toleran terhadap penganut agama lain. Dalam situasi berkecamuknya beragam pemikiran keagamaan, tugas pembina keagamaan dan dosen agama tentu sangat berat. Dalam situasi semacam ini, seolah-

3 Din Syamsuddin M., 2002, Etika Agama dalam Membangun Masyarakat Madani, Ciputat: Logos. Hal. 201-205. olah sedang terjadi pergulatan antara pembinaan keagamaan PTU dengan pemikiran agama yang menjadi mainstream. Yang tidak kalah penting adalah pengaruh kuliah PAI dalam membentuk pemikiran keagamaan dalam organisasi-organisasi keagamaan intra maupun ekstra kampus. Organisasi-organisasi ini jauh lebih intens berkomunikasi dalam mengarahkan pemikiran agama ketimbang pembina resmi kehidupan beragama melalui kuliah PAI.

\section{METODE PENELITIAN}

Metode

Penelitian ini menggunakan metode deskriptif-kuantitatif, yakni suatu penelitian yang berusaha mengungkap permasalahan yang sedang terjadi secara kuantitatif. Selain itu, penelitian ini lebih merupakan studi kebijakan yang didasarkan atas data lapangan.

Oleh karena itu, metode penelitian yang paling tepat untuk kasus ini adalah deskriptif-analitik, yakni suatu penelitian yang berusaha mengungkap permasalahan yang sedang terjadi untuk dideskripsikan, dianalisis, disimpulkan dan direkomendasikan untuk menentukan suatu kebijakan. Data yang tekumpul diolah dan dianalisis dengan statistik deskriptif (\%) dan inferensial (t-test dan chisquare) ataupun secara kualitatif. Adapun untuk mengetahui korelasi kuliah PAI terhadap corak berfikir keagamaan mahasiswa aktivis Islam, baik Eksklusif, Inklusif, dan Liberal, dipergunakan rumus koefisien korelasi yaitu:

$$
r_{x y}=\frac{n \sum X Y-(X)(Y)}{\sqrt{\left[n \sum X^{2}-\left(\sum X\right)^{2}\right]\left[n \sum Y^{2}-\left(\sum Y\right)^{2}\right]}}
$$

Adapun untuk mengetahui besar persentase pengaruhnya dipergunakan rumus Koefisien Determinasi (KD) dengan rumus: $r_{x y}{ }^{2} x$ 100; dimana $r_{x y}$ adalah harga koefisien korelasi. 
Variabel Penelitian

\subsection{Latar Belakang Sosial Keagamaan (X)}

- Keberagaan Keluarga

- Lingkungan Keagamaan

- Pendidikan Keagamaan

- Kuliah PAI di PTU

2.2. Pemikiran Keagamaan (Y)

- Eksklusif Ekstrim

- Eksklusif Moderat

- Inklusif Rendah

- Inklusif Tinggi

- Liberal Moderat

- Liberal Ekstrim

Variabel $Y$ atau variabel terikat dalam penelitian ini adalah corak berpikir keagamaan, menyangkut: (a) eksklusif, (b) inklusif, dan (c) liberal. Masing-masing corak berpikir keagamaan pun dibagi dua, ekstrim dan moderat atau tinggi dan rendah. Sedangkan variabel X-nya atau variabel bebas adalah latar belakang sosiokeagamaan responden, menyangkut: (a) keberagamaan keluarga, (b) lingkungan keagamaan ketika tinggal bersama keluarga, dan (c) program studi (keagamaan/IImu Pendidikan Agama/kePendidikan keagamaan, dan (d) Kuliah Pendidikan Agama Islam di PTU.

Populasi dan Sampel Penelitian

Populasi dalam penelitian ini adalah mahasiswa aktivis Islam di 13 Perguruan Tinggi Umum Negeri terkemuka yang ada di 10 provinsi seluruh Indonesia. Adapun sampelnya ditetapkan dengan penentuan perguruan tinggi yang akan dipilih sebagai sampel, ditetapkan secara purposif-cluster. Dalam hal ini hanya Perguruan Tinggi Umum Negeri yang dikenal memiliki aktivitas keagamaan yang tinggi dan dua PTU Nageri yang minoritas muslim tapi memiliki aktivitas kegamaan yang khas yaitu UDAYANA dan UNPATI yang dipilih sebagai sampel.
Tabel: 1

Perguruan Tinggi Sasaran Penelitian

\begin{tabular}{|c|l|l|}
\hline No. & \multicolumn{1}{|c|}{ WILAYAH PROVINSI } & \multicolumn{1}{|c|}{$\begin{array}{r}\text { PERGURUAN TINGGI } \\
\text { UMUM NEGERI }\end{array}$} \\
\hline 1. & Jawa Barat & UPI dan ITB \\
\hline 2. & Jawa Tengah & UNS \\
\hline 3. & Jawa Timur & ITS dan UNIBRAW \\
\hline 4. & Kalimantan Selatan & UNLAM \\
\hline 5. & Banda Aceh & UNSYIAH \\
\hline 6. & Bali & UDAYANA \\
\hline 7. & Sulawesi Selatan & UNHAS \\
\hline 8. & Ambon & UNPATI \\
\hline 9. & DIY YogJakarta & UGM \\
\hline 10. & DKI Jakarta & UI dan UNJ \\
\hline & JUMLAH & 13 \\
\hline
\end{tabular}

Adapun jumlah samplenya ditetapkan 580 orang mahasiswa aktivis Islam di 13 PTU Negeri, masing-masing 40 s.d. 50 orang aktivis keagamaan dari setiap Perguruan Tinggi objek penelitian. Setelah diverifikasi pada sampel tersebut, maka data yang dapat diolah hanya 506 orang, karena ada non aktivis dan mahasiswa yang belum mengikuti kuliah PAI.

Instrumen Penelitian

Instrumen yang digunakan dalam penelitian ini sebanyak dua (2) buah, yaitu:

a. Pemikiran keagamaan mahasiswa Islam perguruan tinggi umum negeri;

b. Latar sosio-keagamaan mahasiswa Islam perguruan tinggi umum negeri.

Pemikiran keagamaan mahasiswa berbentuk pilihan -ya- dan -tidak- terhadap setiap pernyataan yang diajukan kepada responden. Untuk menghindari jawaban tebakan, maka 33 pernyataan dibuat dalam bentuk positif dan 9 pernyataan lagi negatif, jadi 42 pernyataan. Jika opsi itu tidak sesuai dengan responden, maka mereka tidak dipaksa untuk menjawabnya dengan Ya atau Tidak, melainkan dikosongkan saja (tidak perlu diisi). Akumulasi terhadap jawaban mereka itulah yang menggambarkan kecenderungan pemikiran keagamaan mahasiswa Islam perguruan tinggi umum negeri 
Jumlah opsi dapat diperhatikan dalam kisi-kisi dalam tabel berikut:

Tabel: 2

Kisi-kisi Pemikiran Keagamaan

\begin{tabular}{|c|l|c|}
\hline No. & \multicolumn{1}{|c|}{ Pemikiran Keagamaan } & JUMLAH PERNYATAAN \\
\hline 1 & Eksklusivisme ekstrim & 7 \\
\hline 2. & Eksklusivisme moderat & 7 \\
\hline 3. & Inklusivisme rendah & 7 \\
\hline 4. & Inklusivisme tinggi & 7 \\
\hline 5. & Liberalisme moderat & 7 \\
\hline 6. & Liberalisme ekstrim & 7 \\
\hline & JUMLAH & 42 \\
\hline
\end{tabular}

Pertanyaan-pertanyaan yang diajukan dalam kuesioner menyangkut hal-hal berikut:

a. Penerimaan atau penolakan terhadap beberapa konsep yang diperdebatkan ( Jihad, Khilafah, Imamah, dll ).

b. Penerimaan atau penolakan terhadap isu-isu penegakan syariat Islam (Negara Islam, Hukum Cambuk, Hukum Rajam, Hukum Potong Tangan, Qhishos, Lokalisasi perjudian, dII),

c. Penerimaan atau penolakan terhadap pandangan kegamaan yang berbeda (persoalan sunnah-bid'ah, sunnahsyirik, dII),

d. Penerimaan atau penolakan terhadap madzhab dan organisasi keagamaana yang dipandang berbeda bahkan kontradiktif (Suni-Syi'ah,-Ahmadiyyah. NU-Muhamadiyah-Persis, $\quad$ FPI-HTMMI-FUI-JIL, dII),

e. Penerimaan atau penolakan terhadap tokoh-tokoh yang memiliki corak berpikir keagamaan khas dan berbeda (Gus Dur, Cak Nur, Ulil Absor Abdalah, Habib Riziq, Dr.Azhari, dll).

Untuk menggali data kualitatif disusun pedoman wawancara bagi para pengumpul data. Pedoman wawancara ini merupakan insrumen untuk pegangan tim pengumpul data dalam menggali data kualitatif berkaitan dengan kegiatan ektra kurikuler
Pendidkan Agama Islam di Perguruan Tinggi Umum Negeri seluruh Indonesia.

Hasil wawancara tersebut sangat berguna dalam mengungkap data pelaksanaan kegiatan kurikuler PAI dan kecenderungan animo, persepsi serta pengaruhnya terhadap pembentukan corak berpikir keagamaan mahasiswa PTU Negeri seluruh Indonesia.

\section{TEMUAN PENELITIAN}

Temuan Umum

Secara garis besar, penelitian ini menemukan gambaran pemikiran keagamaan mahasiswa aktivis Islam di PTU Negeri seluruh Indonesiasebagai berikut:

1) Terdapat hubungan asosiatif pemikiran keagamaan dengan jenis kelamin responden.

2) Terdapat hubungan asosiatif pemikiran keagamaan dengan jenis program studi responden.

3) Terdapat hubungan timbale balik pemikiran keagamaan dengan organisasi keagamaan intra kampus.

4) Adanya hubungan asosiatif pemikiran keagamaan dengan ormas keagamaan orang tua responden.

5) Adanya hubungan timbale balik pemikiran keagamaan dengan organisasi masyarakat keagamaan orang tua responden.

6) Adanya hubungan timbale balik kuliah PAl terhadap pemikiran keagamaan responden.

Disamping temuan penelitian di atas, ditemukan juga hal-hal berikut:

a. Pemikiran keagamaan mahasiswa aktivis Islam di PTU Negeri yang cenderung eksklusif dan inklusif sisanya tidak jelas corak berpikirnya.

b. Pemikiran keagamaan para aktivis Islam di PTU cenderung didominasi oleh pemikiran keagamaan hasil pembinaan di luar kampus bukan dari dalam kampus 
sendiri. Karenanya, pembinaan keagamaan bagi mahasiswa PTU melalui perkuliahan Pendidikan Agama Islam perlu dievaluasi dan ditata kembali. Perkuliahan Pendidikan Agama Islam harus dibina oleh para dosen yang memiliki komitmen dakwah dan memiliki lima kompetensi yaitu kompetensi personal, profesional, sosial, pedagogis, dan kompetensi profetik.

c. Pemikiran keagamaan mahasiswa Islam perguruan tinggi umum negeri cenderung inklusif, bahkan liberal dalam tingkatan ekstrim.

d. Pemikiran eksklusif dan inklusif tampaknya lebih merupakan direct-effect dari hasil perkuliahan PAI.

Implikasi dari temuan di atas diperlukan pembinaan keagamaan mahasiswa di luar kampus yang lebih menekankan pada ikut sertanya elemen masyarakat, dalam hal ini para ulama, para da'i dan para mubaligh dalam memberikan arahan terhadap corak berpikir keagamaan para aktivis mahasiswa Islam. Sedangkan di dalam kampus lebih menekankan pada aspek keutuhan dalam pola dan sistem pembinaan antara yang diajarkan di kelas dengan kegiatan-kegiatan keagamaan di luar kelas, seperti melibatkan para aktivis dalam program mentoring atau tutorial PAI sebagai kegiatan ko-kurikuler PAI.

\section{Temuan Khusus}

Hubungan Asosiatif Pemikiran Keagamaan dengan Jenis Kelamin Responden

Hubungan antara variabel latar belakang biografis dan sosio-keagamaan responden dengan corak berpikir keagamaan mahasiswa aktivis Islam dapat diperhatikan dalam tabel-tabel berikut:
Tabel: 3

Peta Pemikiran Keagamaan Mahasiswa dengan Jenis Kelamin ( $n=506$ Responden)

\begin{tabular}{|l|l|c|c|c|c|c|c|}
\hline \multirow{2}{*}{ NO } & \multirow{2}{*}{ CORAK AGAMA } & \multicolumn{2}{|c|}{ LAKI-LAKI } & \multicolumn{2}{c|}{$\begin{array}{c}\text { PEREM- } \\
\text { PUAN }\end{array}$} & \multicolumn{2}{c|}{ TOTAL } \\
\cline { 3 - 8 } & & $\mathrm{F}$ & $\%$ & $\mathrm{~F}$ & $\%$ & $\mathrm{~F}$ & $\%$ \\
\hline 1 & Eksklusif Ekstrim & 113 & 35.42 & 70 & 37.43 & 183 & 36.17 \\
\hline 2 & Eksklusif Moderat & 59 & 18.50 & 35 & 18.72 & 94 & 18.58 \\
\hline 3 & Inklusif Rendah & 59 & 18.50 & 24 & 12.83 & 83 & 16.40 \\
\hline 4 & Inklusif Tinggi & 31 & 9.72 & 12 & 6.42 & 43 & 8.50 \\
\hline 5 & Liberal Moderat & 11 & 3.45 & 14 & 7.49 & 25 & 4.94 \\
\hline 6 & Liberal Ekstrim & 12 & 3.76 & 5 & 2.67 & 17 & 3.36 \\
\hline 7 & $\begin{array}{l}\text { Tidak jelas cor- } \\
\text { aknya }\end{array}$ & 34 & 10.66 & 27 & 14.44 & 61 & 12.06 \\
\hline \multicolumn{2}{|l}{ JUMLAH } & 319 & 100 & 187 & 100 & 506 & 100 \\
\hline
\end{tabular}

Dari tampilan data pada Tabel 3 maka dapat diinterpretasi bahwa terdapat hubungan asosiatif antara pemikiran keagamaan dengan jenis kelamin responden. Adapun rincinnya sebagai berikut:

a. Pada responden dengan jenis kelamin laki-laki (319 orang), diperoleh bahwa mayoritas pemikiran mereka adalah Eksklusif Ekstrim (35,42\%), disusul kemudian Eksklusif Moderat dan Inklusif Rendah (18,50\%), Tidak Jelas Coraknya $(10,66)$, Inklusif Tinggi $(9,72 \%)$, Liberal Ekstrim (3,76\%), dan Liberal Moderat (3,45\%).

b. Pada responden dengan jenis kelamin perempuan (187 orang), diperoleh bahwa mayoritas pemikiran mereka adalah Eksklusif Ekstrim (37,43\%), disusul kemudian Eksklusif Moderat (18,72\%), Tidak Jelas Coraknya (14,44\%), Inklusif Rendah (12,83\%), Liberal Moderat $(7,49 \%)$, Inklusif Tinggi (6,42\%), dan Liberal Ekstrim (2,67\%).

c. Mayoritas pemikiran aktivis mahasiswa Islam baik responden laki-laki maupun perempuan adalah Ekstrim Eksklusif. Namun, perempuan lebih menonjol dari pada laki-laki.

d. Baik responden laki-laki maupun perempuan, sama-sama memiliki persentase yang cukup pada pemikiran yang Tidak Jelas Coraknya, namun perempuan lebih menonjol. Sedangkan pada pemikiran Inklusif, laki-laki lebih menonjol 
dari pada perempuan. Selain itu, samasama memiliki persentase yang rendah pada pemikiran Liberal, baik Ekstrim maupun Moderat.

Hubungan Asosiatif Pemikiran Keagamaan dengan Jenis Program Studi Responden

Tabel: 4

Peta Pemikiran Keagamaan Mahasiswa dengan Program Studi ( $n=506$ Responden)

\begin{tabular}{|l|l|r|c|c|c|c|c|}
\hline \multirow{2}{*}{ NO } & \multirow{2}{*}{ CORAK AGAMA } & \multicolumn{2}{|c|}{ MIPA } & \multicolumn{2}{c|}{ NON MIPA } & \multicolumn{2}{c|}{ TOTAL } \\
\cline { 3 - 8 } & & $\mathrm{F}$ & $\%$ & $\mathrm{~F}$ & $\%$ & $\mathrm{~F}$ & $\%$ \\
\hline 1 & Eksklusif Ektrim & 84 & 39.44 & 96 & 32.76 & 180 & 35.57 \\
\hline 2 & Eksklusif Moderat & 38 & 17.84 & 57 & 19.45 & 95 & 18.77 \\
\hline 3 & Inklusif Rendah & 31 & 14.55 & 52 & 17.75 & 83 & 16.40 \\
\hline 4 & Inklusif Tinggi & 15 & 7.04 & 28 & 9.56 & 43 & 8.50 \\
\hline 5 & Liberal Moderat & 12 & 5.63 & 14 & 4.78 & 26 & 5.14 \\
\hline 6 & Liberal Ektrim & 5 & 2.35 & 13 & 4.44 & 18 & 3.56 \\
\hline 7 & $\begin{array}{l}\text { Tidak jelas cor- } \\
\text { aknya }\end{array}$ & 28 & 13.15 & 33 & 11.26 & 61 & 12.06 \\
\hline JUMLAH & 213 & 100 & 293 & 100 & 506 & 100 \\
\hline
\end{tabular}

Dari tampilan data pada Tabel 4 maka dapat diinterpretasi bahwa terdapat hubungan asosiatif antara pemikiran keagamaan dengan Program Studi responden. Adapun rincinnya sebagai berikut:

a. Pada responden program studi MIPA mayoritas pemikirannya adalah Eksklusif Ekstrim (39,44\%), disusul kemudian Eksklusif Moderat (17,84\%), Inklusif Rendah (14,55\%), Tidak Jelas Coraknya $(13,15 \%)$, Inklusif Tinggi $(7,04 \%)$, Liberal Moderat (5,63\%), dan Liberal Ekstrim (2,35\%).

b. Pada responden program studi NON MIPA mayoritas pemikirannya adalah Ekstrim Eksklusif (32,76\%), disusul kemudian Ekstrim Moderat (19,45\%), Inklusif Rendah (17,75\%), Tidak Jelas Coraknya (11,26\%), Inklusif Tinggi $(9,56 \%)$, Liberal Moderat $(4,78 \%)$, dan Liberal Ekstrim (4,44\%).

c. Mayoritas pemikiran aktivis mahasiswa Islam baik responden program studi MIPA maupun NON MIPA adalah Ekstrim Eksklusif. Namun, program studi MIPA lebih menonjol dari pada program studi NON MIPA.

d. Baik responden program studi MIPA maupun NON MIPA, sama-sama memiliki persentase yang cukup pada pemikiran Inklusif dan Tidak Jelas Coraknya; namun pada corak inklusif (baik tinggi maupun rendah) NON MIPA lebih menonjol dari pada MIPA; adapun yang Tidak Jelas Coraknya, MIPA lebih menonjol dari pada NON MIPA. Sedangkan pada pemikiran liberal, NON MIPA lebih menonjol dari pada MIPA, walaupun selisih tipis $(1,24 \%)$.

Hubungan Asosiatif Pemikiran Keagamaan dengan Organisasi Keagamaan Kampus

Tabel: 5

Peta Pemikiran Keagamaan Mahasiswa dilihat dari Organisasi Keagamaan Kampus ( $\mathrm{n}=506$ Responden)

\begin{tabular}{|l|l|c|c|c|c|c|c|c|c|}
\hline \multirow{2}{*}{ NO } & \multirow{2}{*}{ Pemikiran } & \multicolumn{2}{|c|}{ INTRA } & \multicolumn{2}{c|}{ EKSTRA } & \multicolumn{2}{c|}{ TDK } & \multicolumn{2}{c|}{ TOTAL } \\
\cline { 2 - 10 } & $\mathrm{F}$ & $\%$ & $\mathrm{~F}$ & $\%$ & $\mathrm{~F}$ & $\%$ & $\mathrm{~F}$ & $\%$ \\
\hline 1 & $\begin{array}{l}\text { Eksklusif } \\
\text { Ektrim }\end{array}$ & 161 & 38.52 & 59 & 35.98 & 13 & 19.70 & 233 & 35.96 \\
\hline 2 & $\begin{array}{l}\text { Eksklusif } \\
\text { Moderat }\end{array}$ & 69 & 16.51 & 24 & 14.63 & 18 & 27.27 & 111 & 17.13 \\
\hline 3 & $\begin{array}{l}\text { Inklusif Ren- } \\
\text { dah }\end{array}$ & 68 & 16.27 & 30 & 18.29 & 12 & 18.18 & 110 & 16.98 \\
\hline 4 & Inklusif Tinggi & 31 & 7.42 & 17 & 10.37 & 10 & 15.15 & 58 & 8.95 \\
\hline 5 & $\begin{array}{l}\text { Liberal Mod- } \\
\text { erat }\end{array}$ & 22 & 5.26 & 13 & 7.93 & 3 & 4.55 & 38 & 5.86 \\
\hline 6 & $\begin{array}{l}\text { Liberal } \\
\text { Ektrim }\end{array}$ & 14 & 3.35 & 5 & 3.05 & 3 & 4.55 & 22 & 3.40 \\
\hline 7 & $\begin{array}{l}\text { Tidak jelas } \\
\text { coraknya }\end{array}$ & 53 & 12.68 & 16 & 9.76 & 7 & 10.61 & 76 & 11.73 \\
\hline JUMLAH & 418 & 100 & 164 & 100 & 66 & 100 & 648 & 100 \\
\hline
\end{tabular}

Data di atas menunjukan bahwa dari jumlah responden 506 orang terdapat 142 orang mahasiswa aktif di organisasi intra maupun di organisasi ektra sehingga total responden menjadi 648 orang. Selanjutnya, dari data pada tabel 5 dapat diinterpretasikan bahwa terdapat hubungan asosiatif antara pemikiran keagamaan dengan Organisasi Keagamaan Kampus. Adapun rinciannya sebagai berikut:

a. Pada responden yang aktif di Organisasi Keagamaan Intra Kampus, mayoritas pemikiran keagamaannya adalah Ekstrim Eksklusif (38,52\%), disusul kemudian 
Eksklusif Moderat (16,51\%), Inklusif Rendah (16,27\%), Tidak Jelas Coraknya $(12,68 \%)$, Inklusif Tinggi $(7,42 \%)$, Liberal Moderat (5,26\%), dan Liberal Ekstrim (3,35\%).

b. Pada responden yang aktif di Organisasi Keagamaan Ekstra Kampus, mayoritas pemikiran keagamaannya adalah Eksklusif Ekstrim (35,98\%), disusul kemudian Inklusif Rendah (18,29\%), Eksklusif Moderat (14,63\%), Inklusif Tinggi (10,37\%), Tidak Jelas Coraknya $(9,76 \%)$, Liberal Moderat 7,93\%), dan Liberal Ekstrim (3,05\%).

c. Mayoritas pemikiran aktivis mahasiswa Islam baik mereka yang aktif di Organisasi Keagamaan Intra Kampus, Ekstra Kampus, maupun kedua-duanya adalah Ekstrim Ekslusif, namun mereka yang aktif di Organisasi Intra Kampus lebih menonjol dari pada Ekstra Kampus maupun aktif pada kedua-duanya.

d. Baik responden yang aktif pada Organisasi Keagamaan Intra Kampus, Ekstra Kampus, maupun yang aktif pada Keduanya, memiliki hubungan yang cukup signifikan dengan pemikiran Inklusif, baik Rendah maupun Tinggi. Di samping itu, memiliki persentase yang cukup pada tidak jelas pemikirannya. Serta memiliki persentase yang rendah dengan pemikiran Liberal, baik Moderat maupun Ekstrim.

Hubungan Asosiatif Pemikiran Keagamaan dengan Ormas Keagamaan Orangtua Responden
TABEL 6

Peta Pemikiran Keagamaan Mahasiswa

Dilihat dari Organisasi Keagamaan Orang Tua Mahasiswa

1. ( $n=506$ Responden)

\begin{tabular}{|l|l|c|c|c|c|c|c|c|c|c|c|}
\hline \multirow{2}{*}{ NO } & \multirow{2}{*}{ Pemikiran } & \multicolumn{2}{|c|}{ NU } & \multicolumn{2}{c|}{ MD } & \multicolumn{2}{c|}{ PI dII } & \multicolumn{2}{|c|}{ TDK } & \multicolumn{2}{c|}{ TOTAL } \\
\cline { 3 - 12 } & & $\mathrm{F}$ & $\%$ & $\mathrm{~F}$ & $\%$ & $\mathrm{~F}$ & $\%$ & $\mathrm{~F}$ & $\%$ & $\mathrm{~F}$ & $\%$ \\
\hline 1 & Eksklusif Ektrim & 70 & 27.67 & 40 & 41.67 & 24 & 57.14 & 49 & 42.61 & 183 & 36.17 \\
\hline 2 & $\begin{array}{l}\text { Eksklusif Mode- } \\
\text { rat }\end{array}$ & 45 & 17.79 & 20 & 20.83 & 9 & 21.43 & 22 & 19.13 & 96 & 18.97 \\
\hline 3 & Inklusif Rendah & 61 & 24.11 & 12 & 12.50 & 4 & 9.52 & 7 & 6.09 & 84 & 16.60 \\
\hline 4 & Inklusif Tinggi & 26 & 10.28 & 10 & 10.42 & 0 & 0.00 & 7 & 6.09 & 43 & 8.50 \\
\hline 5 & Liberal Moderat & 11 & 4.35 & 5 & 5.21 & 1 & 2.38 & 6 & 5.22 & 23 & 4.55 \\
\hline 6 & Liberal Ektrim & 5 & 1.98 & 0 & 0.00 & 4 & 9.52 & 7 & 6.09 & 16 & 3.16 \\
\hline 7 & $\begin{array}{l}\text { Tidak jelas } \\
\text { coraknya }\end{array}$ & 35 & 13.83 & 9 & 9.38 & 0 & 0.00 & 17 & 14.78 & 61 & 12.06 \\
\hline JUMLAH & 253 & 100 & 96 & 100 & 42 & 100 & 115 & 100 & 506 & 100 \\
\hline
\end{tabular}

Dari data pada Tabel 6 di atas, dapat diinterpretasikan bahwa terdapat hubungan asosiatif yang sangat nyata antara pemikiran keagamaan dengan ormas keagamaan orang tua responden. Adapun rinciannya sebagai berikut:

a. Pada responden yang orang tuanya mengidentifikasikan dirinya dalam ormas Nahdhatul Ulama, mayoritas corak berpikir keagamaannya adalah Ekstrim Eksklusif (27,67\%), disusul kemudian Inklusif Rendah (24,11\%), Eksklusif Moderat $(17,79 \%)$, Tidak Jelas Coraknya (13,83\%), Inklusif Tinggi $(10,28 \%)$, Liberal Moderat (4,35\%), dan Liberal Ekstrim (1,98\%).

b. Pada responden yang orang tuanya mengidentifikasikan dirinya dalam ormas Muhammadiyah, mayoritas pemikiran keagamaannya adalah Ekstrim Eksklusif (41,67\%), disusul kemudian Eksklusif Moderat (20,83\%), Inklusif Rendah (12,50\%), Inklusif Tinggi $(10,42 \%)$, Tidak Jelas Coraknya (9,38\%), Liberal Moderat (5,21\%), dan Liberal Ekstrim (0\%).

c. Pada responden yang orang tuanya mengidentifikasikan dirinya dalam ormas Persatuan Islam dan lain-lain, mayoritas corak berpikir keagamaannya adalah Eksklusif Ekstrim (57,14\%), 
disusul kemudian Eksklusif Moderat $(21,43 \%)$, Inklusif Rendah dan Liberal Ekstrim (9,52\%), Liberal Moderat (2,38\%), dan Inklusif Tinggi dan Tidak Jelas Coraknya (0\%).

d. Pada responden yang orang tuanya tidak mengidentifikasikan dalam ormas keagamaan, mayoritas corak berpikir keagamaannya adalah Ekstrim Eksklusif $(42,61 \%)$, disusul kemudian Eksklusif Moderat $(19,13 \%)$, Tidak Jelas Coraknya $(14,78 \%)$, Inklusif Rendah, Inklusif Tinggi dan Liberal Ekstrim (6,09\%), dan Liberal Moderat (5,22\%).

e. Dengan melihat frekuensi dan angkaangka persentase pada masing-masing corak dan organisasi keagamaan, responden yang orang tuanya mengidentifikasikan diri dalam ormas Nahdatul Ulama, Muhammadiyah, Persis dll, dan yang tidak menggabungkan diri dengan salah satu ormas lebih menonjol dalam corak berpikir keagamaan yang Eksklusif (terutama Eksklusif Ekstrim), dari pada Inklusif (baik Rendah maupun Tinggi), Tidak Jelas Coraknya, maupun Liberal (baik Moderat maupun Ekstrim).

Hubungan Korelatif Kuliah PAI Terhadap Pemikiran Keagamaan Responden

Tabel: 7

Peta Korelasi Kuliah PAI pada Pemikiran Keagamaan Mahasiswa Aktivis Islam di PTU ( $\mathrm{N}=506$ Responden)

\begin{tabular}{|l|c|c|c|c|c|c|}
\hline NO & $n$ & $\begin{array}{c}\text { Kuliah } \\
\text { PAI } \\
(\mathrm{V}-\mathrm{X})\end{array}$ & $\begin{array}{c}\text { CORAK } \\
\text { AGAMA } \\
(\mathrm{V}-\mathrm{Y})\end{array}$ & $\Sigma$ & \multicolumn{2}{|c|}{ KERPengaruh } \\
\cline { 6 - 8 } & 506 & 1137 & Eksklusif & 4749 & 0,6260 & 39,19 \\
\hline 2 & 506 & 1137 & Inklusif & 3887 & 0,5783 & 33,44 \\
\hline 3 & 506 & 1137 & Liberal & 3317 & 0,5232 & 27,37 \\
\hline \multicolumn{7}{|l}{ JUMLAH } \\
\hline
\end{tabular}

Dari hasil perhitungan (sebagaimana angka-angka yang terdapat dalam Tabel 7) terlihat dan tergambar dengan jelas mengenai hal-hal berikut:

a. Dari jumlah responden $(\mathrm{n}=506)$, dengan jumlah variabel $\mathrm{X}=1137$ dan jumlah $(\Sigma)$ jawaban responden yang termasuk kategori pemikiran Eksklusif (Variabel Y) sebanyak 4749, diperoleh harga korelasi sebesar 0,6260. Selanjutnya dicari persentasenya melalui koefisien determinasi, diperoleh persentase pengaruh sebesar 39,19\%. Dengan demikian, dari data tersebut dapat diinterpretasikan bahwa pengaruh kuliah PAI terhadap pemikiran keagamaan Eksklusif mahasiswa aktivis Islam adalah sebesar $39,19 \%$.

b. Dari jumlah responden $(n=506)$, dengan jumlah variabel $X=1137$ dan jumlah $(\Sigma)$ jawaban responden yang termasuk kategori pemikiran Inklusif (Variabel Y) sebanyak 3887, diperoleh harga korelasi sebesar 0,5783. Selanjutnya dicari persentasenya melalui koefisien determinasi, diperoleh persentase pengaruh sebesar 33,44\%. Dengan demikian, dari data tersebut dapat diinterpretasikan bahwa pengaruh kuliah PAI terhadap pemikiran keagamaan Inklusif mahasiswa aktivis Islam adalah sebesar $33,44 \%$.

c. Dari jumlah responden $(n=506)$, dengan jumlah variabel $X=1137$ dan jumlah $(\Sigma)$ jawaban responden yang termasuk kategori pemikiran Liberal (Variabel Y) sebanyak 3317, diperoleh harga korelasi sebesar 0,5232. Selanjutnya dicari persentasenya melalui koefisien determinasi, diperoleh persentase pengaruh sebesar $27,37 \%$. Dengan demikian, dari data tersebut dapat diinterpretasikan bahwa pengaruh kuliah PAI terhadap corak keagamaan Liberal mahasiswa aktivis Islam adalah sebesar $27,37 \%$.

\section{PENUTUP}

\section{Kesimpulan}

1). Pemikiran keagamaan mahasiswa Islam PTU Negeri cenderung eksklusif dan insklusif coraknya. Kecenderungan corak berpikir keagamaan responden lebih kuat dipengaruhi oleh aktivitas 
dan pemikiran keagamaan di intra kampus. Implikasinya, pembinaan keagamaan bagi mahasiswa PTU pada mahasiswa aktivis Islam di Perguruan Tinggi Umum Negeri di seluruh Indonesia --khususnya perkuliahan Pendidikan Agama Islam--perlu mempertimbangkan kecenderungan berpikir keagamaan mahasiswa, terutama dari aspek penyusunan kurikulum dan model-model pembelajaran agama.

2). Ada kecenderungan pemikiran keagamaan mahasiswa Islam PTU Negeri eksklusif dan insklusif, tapi dalam tematema tertentu mereka pun liberal bahkan cenderung tidak jelas corak berpikirnya. Unsur inklusivisme dan liberalisme pada mereka tampaknya lebih merupakan direct effect dari perkuliahan PAI. Implikasinya, tema-tema dan metode perkuliahan PAI perlu lebih banyak memiliki tema-tema yang plural dengan pendekatan multi-mazhab. Untuk mencapai kondisi yang ideal, maka kurikulum dan model-model pembelajaran PAI di PTU perlu dikaji ulang dan dikembangkan sesuai dengan tuntuan dan kebutuhan mahasiswa.

3). Para mahasiswa Islam mengharapkan mata kuliah agama dapat memberikan jawaban terhadap problematika keagamaan yang mereka hadapi dalam kehidupannya.

4). Kecenderungan responden eksklusif karena mahasiswa Islam kurang mendapatkan jawaban dari kuliah agama. Karena itu, Pendidikan agama diharapkan dapat memberikan arahan terhadap pola pikir dan perilaku mereka. Implikasinya, kuliah PAI perlu diberikan pengantar yang jelas tentang filosofis beragama dan kedudukan mata kuliah agama dalam kurikulum Pendidikan tinggi.

\section{Rekomendasi}

1) Pendidikan Agama Islam di PTU perlu dioptimalkan dengan melibatkan para aktivis untuk direkrut menjadi pem- bimbing dalam kegiatan ko-kurikuler PAl seperti mentoring dan tutorial di bawah koordinasi dan tangung jawab dosen agama. Bahkan lebih jauh lagi, mereka dapat pula direkrut menjadi asisten.

2) Adanya optimalisasi peran masjid kampus, yang dalam hal ini para pembina masjid kampus perlu menata ulang masjid kampus sehingga dapat memfasilitasi dan bahkan mewadahi para aktivis dalam kepengurusan masjid kampus sesuai dengan kapasitasnya.

\section{SUMBER BACAAN}

Alwi Shihab, 1998, Islam Inklusif: Menuju SikapTerbuka dalam Beragama, Bandung: Mizan.

Arifin Assegaf, 2001, "Memahami Sumber Konflik Antar Iman", dalam Sumartana Th., dkk, Pluralisme, Konflik, dan Pendidikan Agama di Indonesia, Yogyakarta: Institut DIAN/Interfidei.

Asjmuni Abdurrahman, 2002, Manhaj Tarjih Muhammadiyah:MetodologidanAplikasi, Yogyakarta: Pustaka Pelajar.

Azyumardi Azra, 2002, Konflik Baru Antar Peradaban: Globalisasi, Radikalisme dan Pluralitas, Jakarta: RajaGrafindo Persada.

Deden Ridwan, M., (Editor, 2001) Tradisi Baru Penelitian Agama Islam, Bandung: Nuansa.

Din Syamsuddin M., 2002, Etika Agama dalam Membangun Masyarakat Madani, Ciputat: Logos.

Fuaduddin dan Cik Hasan Bisri, (Editor, 2002), Dinamika Pemikiran Islam di Perguruan Tinggi, Ciputat: Logos.

Hasyim Asy'ari, Hadratussyaikh, t.t., Risalah Ahlussunnah wa al-Jama'ah.

Imam Baehaqi, (Editor, 2000), Kontroversi Aswaja: Aula Konflik dan Reinterpretasi, Yogyakarta: LKIS. 
Jalaluddin Rakhmat, 2002, Dahulukan Akhlak di Atas Fikih, Bandung: Muthahhari Press.

Mohammad Daud Ali, "Fenomena 'Sempalan' Keagamaan di PTU: Sebuah Tantangan Bagi Pendidikan Agama Islam", dalam Fuaduddin \& Cik Hasan Bisri, (Editor, 2002), Dinamika Pemikiran Islam di Perguruan Tinggi, Ciputat: Logos.
Mujamil Qomar, 2002, NU Liberal: Dari Tradisionalisme Ahlussunnah ke Universalisme Islam, Bandung: Mizan.

Munawar Rahmat dan Anwar Azmi, 2004, "Pendekatan Studi Ushul dan Lintas Mazhab dalam Meningkatkan Pemahaman dan Toleransi Mahasiswa terhadap Persoalan Khilafiah", (Laporan Penelitian), Bandung: Jurusan MKDU FPIPS UPI. 